\title{
Demystifying the University of Nairobi's Academic Quality through Third Party Ranking Assessment
}

\author{
Li Hongbo; Joseph Muiruri Thige; Ssali Max William \\ Jiangsu University, Kenya
}

\begin{abstract}
University of Nairobi is in a race to become internationally and academically viable to an increasingly interconnected world. Its rankings have gradually become an issue of concern in its management of academic stratification in a globally competitive community. Several mechanisms with different methodologies by these ranking systems have been developed to rank the university. Ranking of University of Nairobi (UON) has been done qualitatively and quantitatively. While most of the ranking systems are qualitative, there are those that are quantitative and this study makes a comparison of a qualitative and quantitative assessment of UON through two ranking systems while drawing a correlation with other ranking systems to establish the trajectory of such ranking system and identifying academic bias in their assessment. To achieve this, the study uses a qualitative review to highlight a number of inconsistencies in the methodologies applied to rank UON. Five main ranking tools commonly applied to the world's universities are reviewed, namely Quacquarelli Symonds (QS), Webometrics ranking (WRWU), Times Higher Education (THE), U.S News.com and Academic Ranking of World Universities (ARWU). The study established that bias exists in the rankings thus causing inconsistencies in UON's placement in different rankings. Suggestions for academic transparency through timely publications and quick access to departmental and institutional data for better ranking exercises are proposed.
\end{abstract}

Key Words: Higher education; academic ranking; variances; ranking reliability

\section{INTRODUCTION}

$\mathrm{T}$ he widening availability of education opportunities has increased the desire for better academic assessment, quality and increased reputation attention globally. This resulted in third parties (external reviewers) availing qualitative and quantitative academic assessment of HEIs in their attainment and retention of academic excellence which became a competitive edge for HEIs to gain visibility. In Africa, gaining a higher education degree is considered a great achievement for learners. Having a degree from a reputable HEI is an added advantage for graduates. UON's higher academics through ranking systems (Abad, 2021; Caeiro, 2020). Since higher education is a long-term investment that may be costly to extend, prospective students demand information from universities or other institutions of higher learning that could help them decide. Since then, an increasing number of universities have competed to become highly placed in university rankings.

Individuals refer to university rankings to guide their future employment decisions, while investors to decide on their contributions (Holstein et al., 2018; Lesley, 2018; Kusumawati, 2019; Hung, 2021). Stakeholders and policymakers need to evaluate the research performance of universities and make long-term goals and decisions (Huang, 2012). University rankings also improve public awareness of the importance of higher education and help to bring increased transparency into how universities project their offers of education to the mass audiences (Marcel, 2019; Jacqmin, 2021; Lim, 2021b).

Studies have shown that prospective students and their parents rely on university rankings to make choices about higher education (Brewer et al., 2019; Henry, et al 2020). Governments and non-governmental agencies prefer to fund universities placed at higher ranks, and with proven records of accomplishment. However, the dynamism and inconsistencies of some ranking tools have disenfranchised ranking objectivity especially when ranking indicators are concerned. Despite the dynamism, relevant information regarding university ranking (which mostly aligns their academic quality) and methodologies are still scarce, with those on methodologies still few, and at infancy stage (Aksu, 2018; Knight, \& De, 2018P; Altbach, 2019; Brada et al., 2015; Brooks, 2018; Chowdhury, 2021; Collins \& Park, 2016; Vargas \& Chávez, 2019; Hazelkorn, 2012; Hauptman, 2019; Figueroa, et al 2018; Johnes, 2018; Li, \& Thige, 2017; Song, et al 2018; Han \& Xu, 2019; Jarocka, 2015; Khamala, Makori, \& Njiraine, 2018; Rauhvargers, 2013), while the seemingly relevant studies on the academic quality and ranking of UON posing confounding results (P. G. Altbach et al., 2019; Kaplin, et al, 2019; Hauptman Komotar, 2019; Johnes, 2018). The quest created is for addressing the intrigues underlying the methods used to create ranking of university. This paper concentrates on the intrigues for ranking UON which apparently has been ranked top performing higher education institution in Kenya.

\section{Research overview}

Increasing market-based orientation and the international character of higher education institutions around the globe has lead students, universities and governments objectively taking great interest in knowing the position that a particular center university or other higher education entity has in comparison with other entities. (Jameel, \& Ahmad, 2020; Vargas \& Rodríguez, 2019; Johnes, 2018; Volpato, Valle, \& Bianchetti, 2018). With the massification of universities practically in every continent, the initiatives to obtain independent analysis of quality (via ranking ${ }^{1}$ ) of the universities have increased

\footnotetext{
${ }^{1}$ According to the dictionary, ranking represents a relationship between a set of items such that, for any two items, the first is either ranked "higher than",
} 
rapidly in recent years across many nations (Vargas \& Rodríguez, 2019; Florian, 2007; Johnes, 2018; X. Li \& Thige, 2017; Lin, et al, 2012; Muñoz, Guadalajara, \& Osca, 2020; Pitman, et al 2020; Ng'ethe, 2014).

Ranking systems are inevitable as stakeholder's demand to know how funds invested with universities are managed (Parvez, \& Agrawal, 2019). Leading universities globally enforce the university ranking system as a basis for their internal self-assessment and external overview. This therefore helps them thrust their academic status in order to strengthen their reputation globally. Ranking is therefore essential for strategic planning and enhancement of institutional transparency and stimulating the quality culture in education (Berbegal-Mirabent \& Ribeiro-Soriano, 2015). Consequently, through improved ranking, UON will attract talented, skilled and innovative students and generate more income for the university and for Kenya as a whole.

This review seeks to highlight parameters that constitute qualitative analysis of the UON using third party assessment. And using those parameters against the varying weights allocated for each variance, while pointing out the inconsistencies in the methods applied to rank UON. After a definition of ranking, its importance and implications for the UON, the article reviews the five main ranking tools, namely, Quacquarelli Symonds (QS), Webometrics ranking (WRWU), Times Higher Education (THE), U.S News.com and Academic Ranking of World Universities (ARWU) then using these findings identify the variances UON needs to increase input on to de-gap it's not appearance in the global assessment of best performing HEIs.

\section{Demystifying global HEIs' quality analysis}

The expedition for university ranking has provided both significant and unfavorable externalities to universities when it regards its quality. Generally, universities have made significant contributions to a country's development towards sustainable economic growth (Kiraka, et al 2020). Universities contributed significantly to Taiwan's economy from 1965 to 2000 , where a $1 \%$ increment of universities' stock resulted in a $0.19 \%$ real output increase (Lin, 2004). The study also found that engineering and natural sciences contributed more in terms of nation-building, compared with the humanities fields. Levin (2010) argued that a few countries in East Asia, such as Japan, Singapore, South Korea, Taiwan and Hong Kong, recognized the importance of educated human resources to national economic growth. Therefore, investment in education had reaped the rewards in these countries, particularly with China and India, which are seeking to gain control of the regional economy by 2050. In the chase to elevate their rankings, universities have been under constant pressure to perform their very best (Mussard \& James, 2018). This

"lower than" or "equal to" the second. In mathematics, this is known as a weak order or total preorder of objects. It is not necessarily a total order of objects because two different objects can have the same ranking. includes increasing the volume of publications in reputable academic journals indexed in leading bibliometric data bases, such as Web of Science and Scopus (Shin et al., 2011, p.10).

University managements as well as governments, have for long aspired to better the ranking of their respective universities, a course they seem to expect achieve via increasing human resources, such as the number of researchers and lecturers, and facilities, which are leading indicators in the university ranking exercises (Nafukho, Wekullo, \& Muyia, 2019; Thige, et al 2021). These measures have incurred significant expenditures, which, if improperly managed, could lead to a significant decline in a university's progress. Some reputable universities prefer to invest money in other dimensions that lie in that particular university's vision in terms of principles, socio-economics and culture which are not considered as essential dimensions or indicators in university ranking systems. In other cases, universities are not able to spend because of inefficiencies in using their available funds. In these circumstances, even though a university spends, it does not improve its ranking.

In terms of impact on student fees, university rankings may come with high costs. A university may tend to charge students more if it becomes higher ranked in the available ranking system. In the UK, for instance, universities are increasing their fees by up to 9000 pounds per year (Broecke, 2015). This is creating an unsustainable environment for future generations seeking a chance to study in prestigious and well-known universities, as higher-ranked universities tend to be costlier. Students are increasingly struggling to cope with the fees. Alongside this, students may become trapped in a high amount of debt even before completing their studies. For some people, it does not matter where they have graduated. What matters is getting the job and having less debt. Sometimes, the lower the rank, the lower the fees, and the lower the minimum requirements. In other words, excellent education for less cost is sometimes more attractive than a high-ranking institution and a potentially high amount of debt in the future.

University rankings become a pressure for individual universities because it does affect their activities. Some may respond to the imposed pressure by "overshadowing" their status with historical information with the purpose of "creating narratives that manipulate their rankings to promote their own strengths" (Heffernan \& Heffernan, 2018, p.29). The "overshadow psychology" approach may improve public perceptions and help the university compete, but this is a form of "media spin" and ultimately is not a credit to academic society.

University rankings in the private sector may or may not affect graduates' status in finding a job or career advancement in the present times, as many certifications may be regarded as not specifically relevant to the actual skills required for the employment they are seeking (Reddy et al., 2016). However, high expectations from employers towards recruits graduating from high ranking universities are inevitable. When one is out 
there in the job market, the university's ranking may or may not help. It might help in certain countries, but not all (Pizarro Millian \& Rizk, 2018). The labour market outcome for students was among the expected critical implications of university rankings. However, the question of whether a university's high ranking can guarantee the success of its graduates remains unanswered. In some industries, a university's ranking may or may not help a student in job searching, though for some industries or professions, a university's ranking may play a role, especially in reaching the interview stage of a selection process.

As many graduates may encounter difficulty in finding employment, and may be in debt, some may develop feelings about being trapped in debt as if through an education "scam" in which university ranking was the "bait". In other cases, unless the student gets a full scholarship, getting into a highranking university could lead to feelings about a waste of money. In the case of Jiangsu in China, for example, Li and Thige (2017) commented that students who "did not meet their academic obligation within the set timelines were forced to spend more money to finish".

University ranking may also create a competitive environment among groups of scholars. A study about salary versus ranking has revealed greater inequalities in salary structure among research-orientated institutions, compared to teachingoriented universities (Roth \& McAndrew, 2018). The discrimination appeared to arise from university ranking implications. A university's good ranking may boost the confidence levels of most its academics, but it may incur a risk of academic corruption. A hypothetical example could be a senior lecturer so anxious to attain the title and salary of an associate professor, that he or she is tempted to become named as an author on a student's research paper, though not having made a sufficient contribution warranting authorship. It could be almost impossible to determine whether such an action has occurred, as in many universities postgraduates have to publish as a requirement to graduate. Questioning "How corrupt are universities?", (Sohail, Siddiqui, \& Ali, 2018) drew attention to the discourse about corruption in universities.

University rankings may distort public opinion with a misleading goal (Mussard \& James, 2018). For example, a student seeks specific criteria to decide on the most suitable university, giving thought to his or her learning style, intellectual interests, and location. Some students may use university ranking as a short cut to finding the perfect fit, or maybe just for the sake of seizing an opportunity for a government scholarship. University ranking is also a marketing strategy to attract international students' (Olcay \& Bulu, 2017; Thige, et al 2021). University ranking can be misleading; after all, we do live in a society that values brands and labels. University ranking is being used as a tool to reveal information about the university or its students. However, a more useful measurement tool is needed to match global needs, and be a foundation for how, today, we judge the success of a specific university. Exercising caution when making a choice would be the best action since one size does not fit all, and it varies from person to person. It is now unwise to spend a fortune to gain an education, if selection of university was overly dependent on its ranking. A university project its ranking in a way that hides its core limitations. This is because university ranking typically does not have a good capacity to evaluate universities from all angles (Olcay \& Bulu, 2017). False judgments about university ranking may occur, due to diversities amongst university ranking methods, so ranking should not be the ultimate guide to decision making about applying to be admitted.

Based on the findings above, the study recommends a policy framework that increases faculty absorption into academia particularly for UON to meet the international threshold of 9 to 1 student teacher ratio. The research further proposes an academic tailored policy framework able to heighten efficiency of Kenyans student to actively participate in academia of internationalization at home through online and virtual academic partnership and foreign study support for better skills transfer. Further, a policy framework of academic support for academic funding for Kenyan learners studying abroad. Moreover, an increasingly efficient exchange study programs need be instituted/formulated which would foster academic integration of UON with some of the HEIs that are consistent across the ranking systems as best performing institutions.

\section{RANKING APPROACH: DESIGN AND PARAMETERS}

\section{Ranking Design}

The adaptable ranking systems provides a single integrated score while allowing ordinal ranking of entire institutions, which may however, ineptly place a university ranking especially for case where no intrinsic reason why indicators must focus solely on institutions. Such approaches look at institutions departments or faculties at administrative levels.

One such system is self-aggregated ranking which provides comprehensive departmental level rankings across entire universities. They provide separate rankings for each discipline. Sub-institutional rankings such as; field of study level have no weights attached. Giving no indicators and weights scores and not aggregating to create an overall 'score', meaning that no institution is declared 'best', rather, results are posted online and users of the rankings create their own rankings by selecting the indicators which are of interest to them and then receiving personalized result summaries based on their choices.

An insight of input and performance of higher education while doing a comparison view of high end integrated grown and developed academically global universities has the analogy done in view of such universities as UON academia verses leading top Ranked Global Universities, and, while aiming to demonstrate the ranking nature of the ranking systems. The ranking based on the 2019 University Ranking is implored by THE \& WRWU. Though all of top ranked HEIs perform better than UON in all programs including arts and sciences, 
all the other academic programs push UON below the HEI's aggregated and positioned within its cutoff numeric assessment with UON aggregating lower than all other HEIs ranked.

From the analogy, the credibility and trust of any ranking depends on methodological quality which show feasibility, validity and reliability on a broad spectrum of the indicators used and the weights the indicators carry. According to the data available in UON's website, there is validity in stating that the data source is feasible, however, the report in the website cannot be used for purposes of ranking because contents may not be a neutral assessment of the University but rather stimulated by the wish to present UON as positively as possible. It's worth to note that UON delays releasing its annual report for 5 years.

It is also worth to note that UON has 7 independent campuses each collecting its data then sending it to the main campus for verification, analysis and synthesis, the entire process takes five academic years rendering the report irrelevant to aggregate UON and even consider it in the THE, QS, US News.com or ARWU annual ranking, only leaving WRWU which uses quantification numerical assessment apart from academic output to aggregate. But, this makes UON less visible regionally and globally and thus affects both its outlook and external quality assessment.

Thus, section which tested the usefulness of the Ranking Theory (WRWU, THE, QS, ARWU and U.S.News.com against UON, the theory tested THE \& WRWU which both ranked UJS \& UON and their diversification and explained how UON can benchmark itself against THE through indicators and weights and subjects taught. If an institution of the level of UON benchmarks itself against a world Class Ranking System, it will become more appealing to its consumers who are current and future academic intakes.

The ranking gave specific information to its readers about assessment of quality and therefore was considered as the more elaborate the ranking system thus creating better informed consumers of Higher Education Institutions (HEIs). Some unique features for evaluation of UON's quality assurance which in turn affected their outlook include assessment. Though UON was not academically ranked by QS, ARWU and U.S.News.com in previous years of assessment namely 2014-2019 academic years, these being among the top bench markers of the quality evaluation within the ranking systems and gradually noticing the visibility of UON as contained in 2019's (THE, WRWU and QS ranking systems), 2020's (THE \& WRWU, U.S.News \& World Report ranking systems) and 2021' (THE, WRWU and U.S.News \& World Report assessment). Reference below.

\begin{tabular}{|c|c|c|c|}
\hline \multicolumn{4}{|c|}{ Table 1. Comparative Global Rankings of UON by THE, WRWU QS \& } \\
\hline $\begin{array}{c}\text { Ranking } \\
\text { system/year }\end{array}$ & 2019 & 2020 & 2021 \\
\hline THE & 1001 & 801 & 601 \\
\hline $\begin{array}{c}\text { U.S. News \& } \\
\text { World Report }\end{array}$ & - & 867 & 792 \\
\hline QS & 801 & - & - \\
\hline WRWU & 1242 & 1193 & 1055 \\
\hline
\end{tabular}

Source: THE www.timeshighereducation.com; QS www.topuniversities.com; WRWU www.webometrics.info/en ; ARWU www.arwu.org; and, U.S.news.com http://www.u.s.news.com; /2019-2021.Retrieved: 05/04/2021, Rank criterion of international academics ranking:-.

The Ranking Web or Webometrics is the largest academic ranking of Higher Education Institutions. Since 2004 and every six months Cybernetics Lab (Spanish National Research Council, CSIC) provides an assessment of the performance of universities from all over the world based on their web presence and impact.

\section{Parameters: Quality assessment ranking parameters}

This section presents an in-depth view of the ranking parameters for respective ranking systems with weights indicated and for respective indicators. We can clearly infer from Table 1 that ranking systems presented, row-wise include ARWU, THE, QS, U.S News.com and WRWU for the respective columned parameter (Research, Citation, Publication and performance). Overall, we notice that there underlie respective observable parameters for each virtual indicator. That is, the research aspect is represented using the observed parameters; research output, research itself, research quality, global research reputation, and presence while citation is indicated by citation itself, citation impact, and normalized citation impact. The case regarding publication is done by publication, and openness among others. The case regarding performance is also well indicated using variables like international outlook, collaboration and per capita performance. The general overview of the Table created is that the systems may be categorized into qualitative or qualitative type of ranking system based on the associated weight on the indicator. To be specific systems like ARWU specifically uses the indicators research output, publication and citation and impact all weighted at $20 \%$ while the per capita performance and quality of education are weighted at $10 \%$ in that order. THE uses research and teaching, citation weighted at $30 \%$ and $32.5 \%$ respectively industry income at $2.5 \%$ and international outlook at 5\%. For US News.com research reputation weights at $12.5 \%$, publication, citation and total at $10 \%$ and $7.5 \%$, conferences $2.5 \%$, number of publications $12.5 \%$ while books are weighted at $2.5 \%$. For WRWU, the weights are 5\% for presence, $50 \%$ and $10 \%$ for visibility and transparency, while excellent scholar takes $35 \%$. The indicators have also been widely used in studies venturing the impact of ranking systems and or the relationship with the academic quality of various universities. 


\begin{tabular}{|c|c|c|c|c|c|c|c|c|c|c|c|}
\hline & \multirow[b]{2}{*}{ Category } & \multicolumn{2}{|c|}{ ARWU (2003) } & \multicolumn{2}{|c|}{ THE (2009) } & \multicolumn{2}{|l|}{ QS (2009) } & \multicolumn{2}{|c|}{ U.S.News.com (2008) } & \multicolumn{2}{|c|}{ WRWU (2004) } \\
\hline & & Indicators & Weight & Indicators & Weight & Indicators & Weight & Indicators & Weight & Indicators & Weights \\
\hline \multirow{2}{*}{1} & \multirow{2}{*}{ Research } & $\begin{array}{c}\text { Research } \\
\text { Output }\end{array}$ & $20 \%$ & Research & $30 \%$ & Research quality & $40 \%$ & $\begin{array}{c}\text { Global Research } \\
\text { reputation }\end{array}$ & $12.5 \%$ & presence & $5 \%$ \\
\hline & & - & - & - & - & - & - & $\begin{array}{l}\text { Regional Research } \\
\text { reputation }\end{array}$ & $12.5 \%$ & - & - \\
\hline \multirow{3}{*}{2} & \multirow{3}{*}{ Citations } & - & - & & & - & - & Conferences & $2.5 \%$ & Visibility & $50 \%$ \\
\hline & & $\begin{array}{l}\text { Citation } \\
\text { impact }\end{array}$ & $20 \%$ & Citations & $32.5 \%$ & & & $\begin{array}{c}\text { Normalized } \\
\text { Citation impact }\end{array}$ & $10 \%$ & - & - \\
\hline & & $\begin{array}{c}\text { Total } \\
\text { citations }\end{array}$ & $20 \%$ & - & - & - & - & Total Citations & $7.50 \%$ & - & - \\
\hline \multirow{4}{*}{3} & \multirow{4}{*}{ Publications } & Publications & $20 \%$ & - & - & - & - & Publications & $10 \%$ & Transparency/openness & $10 \%$ \\
\hline & & - & - & - & - & - & - & $\begin{array}{l}\text { \# of Publications } \\
\text { among the } 10 \text { cited } \\
\text { journals }\end{array}$ & $12.50 \%$ & - & - \\
\hline & & - & - & - & - & - & - & $\begin{array}{l}\text { Percentage of total } \\
\text { Publications }\end{array}$ & $10 \%$ & - & - \\
\hline & & - & - & - & - & - & - & Books & $2.5 \%$ & - & - \\
\hline \multirow{3}{*}{4} & \multirow{3}{*}{ Performance } & $\begin{array}{c}\text { Per-capita } \\
\text { performance }\end{array}$ & $10 \%$ & $\begin{array}{c}\text { International } \\
\text { outlook }\end{array}$ & $5 \%$ & International outlook & $10 \%$ & $\begin{array}{l}\text { International } \\
\text { collaboration }\end{array}$ & $10 \%$ & Excellence/scholar & $35 \%$ \\
\hline & & $\begin{array}{l}\text { Quality of } \\
\text { education }\end{array}$ & $10 \%$ & $\begin{array}{l}\text { Industry } \\
\text { income }\end{array}$ & $2.5 \%$ & $\begin{array}{c}\text { Graduate } \\
\text { employability }\end{array}$ & $10 \%$ & $\begin{array}{c}\text { Number of PHDs } \\
\text { awarded }\end{array}$ & $5 \%$ & - & - \\
\hline & & - & - & Teaching & $30 \%$ & Teaching quality & $40 \%$ & $\begin{array}{l}\text { Number of PHDs } \\
\text { awarded per } \\
\text { academic year }\end{array}$ & $5 \%$ & - & - \\
\hline
\end{tabular}

\section{FINDINGS}

Over 10 years, WRWU aggregation of UON based on biannual assessment using four variances and the weights allocated with $5 \%$ being the lowest and $50 \%$ being the highest on presence and visibility respectively. In this period of higher education ranking and basing on WRWU rank data; the period seems to depict UON as to have the highest level of aggregation advantage nationally based on its institutional and academic setup.

The university ranks best in Kenya in all years reviewed while it improved exponentially in the first half of the period under review both regionally and globally from position $29^{\text {th }}$ to position $9^{\text {th }}$ and from position $4046^{\text {th }}$ to position $1624^{\text {th }}$ respectively. In the second half of the period under review, the university fluctuates from position $9^{\text {th }}$ to position $8^{\text {th }}$ regionally with $11^{\text {th }}$ being their least performance and $7^{\text {th }}$ being the best. Globally, the trend in the first half of the period under review also shows an improved ranking from position $4046^{\text {th }}$ in Jan 2009 to position $1624^{\text {th }}$ in July 2013 giving an aggregate of $2835^{\text {th }}$ for the five years' period under review. The second period under review shows a fluctuation in global ranking with the least ranked aggregate being $1167^{\text {th }}$ and $789^{\text {th }}$ being the best performed aggregation. This gives a second average aggregate of $978^{\text {th }}$ for the five years under review.

This downward trend in the university ranking may inevitably be de-linked to a number of factors which might include the academic and numerical data as contained in table 5 with the most impactful according to this study being internationalization where UON has $1 \%$ of its entire student population being foreign and student to teacher ratio being 30 to 1 , which might affect quality supervision and timely assessment of the students' academic growth. Other factors might include five years' delay in data release based on its annual report publication thus limiting access to the ranking systems who use this data to make an analysis and assessment for ranking through publications, citations, industry and income and technological advancement while also having a conglomeration diversity based on ethnicity, of both students and faculty members, as a result, they produced the highest numbers of high impact papers cited in the period 2009-2019. As per the specific statistics and regional demographics created by the citations, impacts and ranking, this could be grounds for future researchers to explore and suggest what Higher education institutions can do to encourage inter institutional citations.

\section{UON RANK STATUS: LOCALIZED POSITIONS.}

Having garnered some quality grounds in the side of higher academia - both locally and internationally - it would be unsound if ranking systems disregards the contribution and caliber of University of Nairobi. The giant UON which by size is the biggest university in Kenya and comparatively bigger than most universities globally have not had its potential appreciated in a grander scale comparatively either because of perception or poor academic visibility. The university however has some of the best performing departments in Kenya and the African continent, based on its academic positioning by the ranking systems as referenced in table 1. Poor visibility or perception in return locks out UON's potential and may even affect policy, students and faculty morale and even discourage international students coming from countries with a wider scope of discipline choices from considering UON as their institutions of choice. 
Additionally, The University of Nairobi, as a top national and continental performing Higher Education Institution in its country and among some of the best improving HEIs in the region as globally assessed by some of the most reputable Ranking systemsUON as the baseline institution for current study has broken ranks and emerged as a rapidly growing HEI based on the THE, U.S.News \& World Report, URWU \& QS rankings reports and through global comparison with it recognizing itself as an academic giant in the country (Kenya). The intent that, (UON) as key East Africas' rapidly developing higher education institution, when basing on academic and reputational assessment facilitates the need to correlate the academic quality of the university which is benchmarked in comparison to similar modestly improving HEI's in kenya. And, this is despite stiff competition by other emerging HEI's in Kenya which in some areas out performed UON. Refer to table 2. The fact that, there outlays certain variances where other HEIs in Kenya outperform UON and vice versa create an enabling academic environment for societal transformation through research and policy framework transformation. The fact that these HEIs create visibility shows that global comparisons for a similar global aggregation especially using some parameters of education quality still exist for purposes of better performance.

Moreover, relevant studies on the quality of higher education either singly or while entangling UON with other local and regional universities (with much weight placed within the Sub-Saharan and Asian,) have largely underscored the educational quality of UON on the global scene (Hezelkon 2013; Suarez 2020; Nquyen 2015; Munaglav 2017) while those entangling UON in the comparison are yet scarce, leading to the need for an in-depth analysis of the academic quality of UON and other Kenyan, African and emerging economies based institutions, from both horizontal and Vertical comparison scale

Therefore, a view of its localized ranking by WRWU in Table 2 depicts to some significant contributions of UON to quality as far as relevance in field of higher academics is under concern. The countries top tier universities((UON, Egerton, KU, Moi, JKUAT, TUK, Maseno, Strathmore, MMUST and Embu university)) have been aggregated on WRWU ranking systems based on some relevant rank parameters (impact, openness, excellence, continental and world rank). In all rank places, the university has "good number rank" except for impact rank where Egerton university came first after the country's giant university. The implication created is that UON has better socio-academic and economic quality qualities placing $\mathrm{t}$ best in comparison to other top universities in the country.

\begin{tabular}{|c|c|c|c|c|c|}
\hline \multicolumn{2}{|c|}{ Table 2. WRWU Ranking of universities in Kenya 2020-2021 } \\
\hline University & $\begin{array}{c}\text { Impact } \\
\text { Rank }\end{array}$ & $\begin{array}{c}\text { Openness } \\
\text { Rank }\end{array}$ & $\begin{array}{c}\text { Excellence } \\
\text { Rank }\end{array}$ & $\begin{array}{c}\text { Continental } \\
\text { Rank }\end{array}$ & $\begin{array}{c}\text { World } \\
\text { Rank }\end{array}$ \\
\hline University of Nairobi & 1180 & 616 & 1637 & 10 & 1055 \\
\hline Egerton University & 889 & 3223 & 3224 & 23 & 1889 \\
\hline Kenyatta University & 1674 & 1196 & 3224 & 25 & 1923 \\
\hline Moi University & 3799 & 1504 & 2702 & 29 & 2156 \\
\hline $\begin{array}{c}\text { Jomo Kenyatta } \\
\text { University of } \\
\text { Agriculture and } \\
\text { technology }\end{array}$ & 3910 & 1273 & 2754 & 30 & 2160 \\
\hline $\begin{array}{c}\text { Technical University of } \\
\text { Kenya }\end{array}$ & 4314 & 3222 & 4934 & 80 & 3859 \\
\hline $\begin{array}{c}\text { Maseno University } \\
\text { Strathmore University } \\
\text { Nairobi }\end{array}$ & 10947 & 1623 & 4163 & 86 & 4018 \\
\hline $\begin{array}{c}\text { Masinde Muliro } \\
\text { University of Science \& } \\
\text { Technology }\end{array}$ & 12620 & 2931 & 5201 & 119 & 5183 \\
\hline $\begin{array}{c}\text { University of Embu } \\
\text { Note: Rank status of UON from localized scale of top performing universities. Source:- }\end{array}$ & 2995 & 3947 & 5201 & 93 & 5099 \\
\hline
\end{tabular}

When the consideration regards ranking status of the UON over ten-year period, we notice its performance as generally improving slightly as majority ranks depicts. The rank curve by continental rank and world rank is gently dropping since inception to rest of the period, for an indication that UON has been gaining an increasing significance over time. Similar notation can be realized when the case regards presence rank, openness rank, impact rank and scholarly work rank, refer to table 3 .

\begin{tabular}{|c|c|c|c|c|c|c|c|c|c|c|c|c|c|c|c|c|c|c|c|c|c|}
\hline \multicolumn{22}{|c|}{ Table 3. UON- Webometrics Ranking (over a 10-year period)- 2009 to 2019} \\
\hline & $\begin{array}{c}\text { Jan- } \\
09\end{array}$ & $\begin{array}{c}\text { Jul- } \\
09\end{array}$ & $\begin{array}{l}\text { Jan } \\
-10\end{array}$ & $\begin{array}{c}\text { Jul } \\
- \\
10 \\
\end{array}$ & $\begin{array}{c}\text { Jan } \\
-11\end{array}$ & $\begin{array}{c}\text { Jul } \\
- \\
11 \\
\end{array}$ & $\begin{array}{l}\text { Jan } \\
-12\end{array}$ & $\begin{array}{c}\text { Jul } \\
- \\
12 \\
\end{array}$ & $\begin{array}{l}\text { Jan } \\
-13\end{array}$ & $\begin{array}{c}\text { Jul } \\
- \\
13 \\
\end{array}$ & $\begin{array}{l}\text { Jan } \\
-14\end{array}$ & $\begin{array}{c}\text { Jul } \\
- \\
14 \\
\end{array}$ & $\begin{array}{l}\text { Jan } \\
-15\end{array}$ & $\begin{array}{c}\text { Jul } \\
- \\
15 \\
\end{array}$ & $\begin{array}{l}\text { Jan } \\
-16\end{array}$ & $\begin{array}{c}\text { Jul } \\
- \\
16 \\
\end{array}$ & $\begin{array}{l}\text { Jan } \\
-17\end{array}$ & $\begin{array}{c}\text { Jul } \\
- \\
17 \\
\end{array}$ & $\begin{array}{l}\text { Jan } \\
-18\end{array}$ & $\begin{array}{c}\text { Jul } \\
- \\
18 \\
\end{array}$ & $\begin{array}{l}\text { Jan } \\
-19\end{array}$ \\
\hline Continental Rank & 29 & 24 & 28 & 26 & 27 & 26 & 17 & 14 & 12 & 9 & 9 & 10 & 8 & 8 & 7 & 11 & 8 & 7 & 10 & 9 & 8 \\
\hline World Rank & $\begin{array}{c}404 \\
6\end{array}$ & $\begin{array}{c}446 \\
7\end{array}$ & $\begin{array}{l}38 \\
97\end{array}$ & $\begin{array}{l}31 \\
90\end{array}$ & $\begin{array}{l}31 \\
36\end{array}$ & $\begin{array}{l}24 \\
52\end{array}$ & $\begin{array}{l}13 \\
67\end{array}$ & $\begin{array}{l}14 \\
35\end{array}$ & $\begin{array}{l}13 \\
26\end{array}$ & $\begin{array}{l}16 \\
24\end{array}$ & $\begin{array}{l}11 \\
67\end{array}$ & $\begin{array}{c}90 \\
7\end{array}$ & $\begin{array}{c}83 \\
4\end{array}$ & $\begin{array}{c}84 \\
1\end{array}$ & $\begin{array}{c}78 \\
9\end{array}$ & $\begin{array}{l}12 \\
85\end{array}$ & $\begin{array}{c}89 \\
0\end{array}$ & $\begin{array}{c}79 \\
6\end{array}$ & $\begin{array}{l}11 \\
31\end{array}$ & $\begin{array}{l}10 \\
08\end{array}$ & $\begin{array}{c}97 \\
1\end{array}$ \\
\hline Presence/Size & $\begin{array}{c}306 \\
9\end{array}$ & $\begin{array}{c}249 \\
0\end{array}$ & $\begin{array}{l}31 \\
36\end{array}$ & $\begin{array}{l}19 \\
05\end{array}$ & $\begin{array}{l}19 \\
76\end{array}$ & $\begin{array}{l}20 \\
45\end{array}$ & $\begin{array}{c}63 \\
1\end{array}$ & $\begin{array}{c}83 \\
9\end{array}$ & $\begin{array}{l}15 \\
28\end{array}$ & $\begin{array}{c}61 \\
9\end{array}$ & $\begin{array}{l}18 \\
28\end{array}$ & $\begin{array}{l}11 \\
09\end{array}$ & $\begin{array}{c}79 \\
8\end{array}$ & $\begin{array}{l}12 \\
56\end{array}$ & $\begin{array}{l}15 \\
01\end{array}$ & $\begin{array}{c}90 \\
6\end{array}$ & $\begin{array}{l}18 \\
34\end{array}$ & $\begin{array}{c}91 \\
8\end{array}$ & $\begin{array}{c}73 \\
4\end{array}$ & $\begin{array}{l}11 \\
80\end{array}$ & $\begin{array}{c}69 \\
2\end{array}$ \\
\hline $\begin{array}{c}\text { Visibility/Openness } \\
\text { Rank } \\
\end{array}$ & $\begin{array}{c}541 \\
3 \\
\end{array}$ & $\begin{array}{c}700 \\
1\end{array}$ & $\begin{array}{l}46 \\
79 \\
\end{array}$ & $\begin{array}{l}41 \\
19 \\
\end{array}$ & $\begin{array}{l}43 \\
35 \\
\end{array}$ & $\begin{array}{l}42 \\
15 \\
\end{array}$ & $\begin{array}{l}17 \\
94 \\
\end{array}$ & $\begin{array}{l}20 \\
10 \\
\end{array}$ & $\begin{array}{l}29 \\
81 \\
\end{array}$ & $\begin{array}{l}28 \\
83 \\
\end{array}$ & $\begin{array}{l}18 \\
98 \\
\end{array}$ & $\begin{array}{l}22 \\
25 \\
\end{array}$ & $\begin{array}{c}19 \\
4 \\
\end{array}$ & $\begin{array}{l}17 \\
89 \\
\end{array}$ & $\begin{array}{l}20 \\
41 \\
\end{array}$ & $\begin{array}{l}20 \\
90 \\
\end{array}$ & $\begin{array}{l}14 \\
89 \\
\end{array}$ & $\begin{array}{c}83 \\
3 \\
\end{array}$ & $\begin{array}{c}92 \\
8 \\
\end{array}$ & $\begin{array}{l}14 \\
89 \\
\end{array}$ & $\begin{array}{c}97 \\
0 \\
\end{array}$ \\
\hline Rich files/Impact Rank & $\begin{array}{c}385 \\
1 \\
\end{array}$ & $\begin{array}{c}432 \\
7 \\
\end{array}$ & $\begin{array}{l}43 \\
63 \\
\end{array}$ & $\begin{array}{l}34 \\
47 \\
\end{array}$ & $\begin{array}{l}33 \\
10 \\
\end{array}$ & $\begin{array}{l}49 \\
42 \\
\end{array}$ & $\begin{array}{l}27 \\
61 \\
\end{array}$ & $\begin{array}{l}40 \\
57 \\
\end{array}$ & $\begin{array}{c}95 \\
0 \\
\end{array}$ & $\begin{array}{l}11 \\
19 \\
\end{array}$ & $\begin{array}{c}77 \\
4 \\
\end{array}$ & 44 & $\begin{array}{c}52 \\
0\end{array}$ & $\begin{array}{c}72 \\
1 \\
\end{array}$ & $\begin{array}{l}31 \\
97 \\
\end{array}$ & $\begin{array}{l}22 \\
81 \\
\end{array}$ & $\begin{array}{c}49 \\
6 \\
\end{array}$ & $\begin{array}{l}23 \\
55 \\
\end{array}$ & $\begin{array}{c}83 \\
9 \\
\end{array}$ & $\begin{array}{c}54 \\
7 \\
\end{array}$ & $\begin{array}{c}74 \\
3 \\
\end{array}$ \\
\hline $\begin{array}{l}\text { Excellent Rank/ } \\
\text { Scholarly work }\end{array}$ & $\begin{array}{c}383 \\
9 \\
\end{array}$ & $\begin{array}{c}371 \\
1\end{array}$ & $\begin{array}{l}41 \\
04\end{array}$ & $\begin{array}{l}38 \\
09 \\
\end{array}$ & $\begin{array}{l}43 \\
82 \\
\end{array}$ & $\begin{array}{l}17 \\
06 \\
\end{array}$ & $\begin{array}{l}17 \\
24 \\
\end{array}$ & $\begin{array}{l}13 \\
42 \\
\end{array}$ & $\begin{array}{l}13 \\
46 \\
\end{array}$ & $\begin{array}{l}13 \\
23 \\
\end{array}$ & $\begin{array}{l}13 \\
29 \\
\end{array}$ & $\begin{array}{l}14 \\
03 \\
\end{array}$ & $\begin{array}{l}14 \\
02 \\
\end{array}$ & $\begin{array}{l}13 \\
86 \\
\end{array}$ & $\begin{array}{l}18 \\
22 \\
\end{array}$ & $\begin{array}{l}12 \\
47 \\
\end{array}$ & $\begin{array}{l}14 \\
21\end{array}$ & $\begin{array}{l}13 \\
83 \\
\end{array}$ & $\begin{array}{l}13 \\
98 \\
\end{array}$ & $\begin{array}{l}12 \\
69 \\
\end{array}$ & $\begin{array}{l}14 \\
88 \\
\end{array}$ \\
\hline
\end{tabular}

\subsection{Comparative ranking of UON-Global scene}

Largely, there are still disagreements among the authors of these indicators as to what indicates quality. The world's main ranking systems bear little if any relationship to one another, using very different indicators and weightings to arrive at a measure of quality (Usher and Savino 2006). 
Usher and Savino (2006) discusses 4 sets of league tables from around the world where they update their ranking results by recording changes in methodology in a few of these rankings, as well as providing data on WRWU as new systems of Global rankings. Specifically, the researcher compares these league tables in terms of their methods of data collection and their selection and weighting of indicators, and also look at Jiangsu University as a HEI. Additionally, they seek to address why the Gap still exists despite its conglomeration and diversity in academic disciplines, and the high percentage of increasing international recognition portrayed through high and growing students' intake.

Based on the aims of this paper, a qualitative review of the underlying antecedent-development literature concerning the ranking systems of higher academia is closely executed, and the outcome analyzed to identify the nature of the underlying and the emerging ranking systems in an effort to understand the development dynamics of education quality amid UON and UJS. This is in fulfillment of the first and the second objective of current study.

In contrast to this approach, other researchers have shown that one of the main causes of institutional unease is the tendency of institutional ranking schemes to use weighted aggregates of indicators to arrive at a single, all-encompassing quality 'score', which in turn would permits institutions to be ranked against one another (as in table 1). By selecting a particular set of indicators and assigning each a given weight. By this, the authors of these rankings are imposing a specific definition of quality on the institutions being ranked. Though Jiangsu University may meet some indicators set, it may be unable to convincingly close the Gap of disparities based on the variables set by strictly adhering with this technique of ranking.

The comparative analogy created in Table 3, on the other hand, depicting the ranking of UON based on various global indicators is apparently pointing to some ranking dynamics for the implication of the various ranking weights or indicators given ranking system implores. For the three-year period, the rank by THE seems to have improved the ranking of UON by a slump while the ranking by U.S News and world report slightly improved the ranking of UON. The ranking by QS and WRWU at this case seems to have been an outlier especially when their ranking is compared with those of the former two ranking systems.

Further, when the ranking performance of UON is compared to that of other universities there seems to be some significant insights noted. Figure 1 depicts the comparison of UON done to that of a similar rapidly emerging Asian university: Jiangsu university and other top performing world universities. Thus, from the Figure we can read that, both country ranking versed continental and world ranking of the universities is done, besides the ranking based on the presence, impact rank, openness, and the excellence rank. The realization created at glance is that a university with best global ranking may uncertainly be best performing and leading when ranked countrywide. Before instance. Oxford university that is best and leading on the country specific scale is ranked $3^{\text {rd }}$ on the global scale. Since UON (with global rank 990) is the main university of interest, we read that, overall, it's in the bottom tire of the rank for all indicators considered, but almost in the same category as Jiangsu university ranked position 702 globally. When based on other ranking criterions such as presence rank, impact, openness and the excellent ranks, they still show that university of Nairobi is in the bottom line after Jiangsu university.

\begin{tabular}{|c|c|c|c|c|c|c|c|}
\hline \multicolumn{8}{|c|}{$\begin{array}{l}\text { Comparative analysis of Webometrics Ranking of } \\
\text { Top eight leading HEls with UJS \& UON based on } \\
2500 \text { http://www.webometrics.info/en's data analysis }\end{array}$} \\
\hline \multicolumn{8}{|l|}{1500} \\
\hline \multicolumn{8}{|l|}{1000} \\
\hline 500 & & & & & & & \\
\hline 0 & & 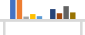 & & & & 1 & \\
\hline & $\begin{array}{l}\text { Cou } \\
\text { ntry } \\
\text { rank } \\
\text { ing }\end{array}$ & $\begin{array}{c}\text { Pres } \\
\text { enc } \\
\text { e }\end{array}$ & $\begin{array}{c}\text { Imp } \\
\text { act } \\
\text { Ran } \\
k\end{array}$ & $\begin{array}{c}\text { Ope } \\
\text { nne } \\
\text { ss } \\
\text { Ran } \\
\text { k }\end{array}$ & $\begin{array}{l}\text { Exce } \\
\text { llent } \\
\text { Ran } \\
k\end{array}$ & $\begin{array}{c}\text { cont } \\
\text { inen } \\
t \\
\text { rank } \\
\text { ing }\end{array}$ & $\begin{array}{l}\text { Wor } \\
\text { Id } \\
\text { Ran } \\
\text { king }\end{array}$ \\
\hline $\begin{array}{l}\text { University of } \\
\text { Nairobi }\end{array}$ & 1 & 261 & 839 & 1217 & 1580 & 8 & 990 \\
\hline Diangsu University & 70 & 2084 & 1246 & 1493 & 500 & 127 & 702 \\
\hline Havard University & 1 & 38 & 2 & 1 & 1 & 1 & 1 \\
\hline Stanford University & 2 & 61 & 3 & 2 & 3 & 2 & 2 \\
\hline $\begin{array}{l}\text { Massachusetts } \\
\text { Institute of } \\
\text { Technology (MIT) }\end{array}$ & 3 & 42 & 1 & 4 & 11 & 3 & 3 \\
\hline $\begin{array}{c}\text { University of } \\
\text { Oxford }\end{array}$ & 1 & 1 & 14 & 10 & 4 & 1 & 4 \\
\hline $\begin{array}{l}\text { University of } \\
\text { california Berkeley }\end{array}$ & 4 & 109 & 4 & 3 & 16 & 4 & 5 \\
\hline $\begin{array}{l}\text { University of } \\
\text { Michigan }\end{array}$ & 5 & 68 & 7 & 13 & 5 & 5 & 6 \\
\hline $\begin{array}{l}\text { University of } \\
\text { Washington }\end{array}$ & 6 & 139 & 6 & 43 & 7 & 6 & 7 \\
\hline - Cornell University & 7 & 77 & 5 & 35 & 22 & 7 & 8 \\
\hline
\end{tabular}

Figure 1. Comparison of university of Nairobi against other top performing universities

\section{CONCLUSION}

This paper concludes that the ranking exercises applied by the above tools can be prone to preferences and favoritisms in terms of cultural, social and historical values (Berbegal Mirabent \& Ribeiro-Soriano, 2015; Liu (2009).. Universities that are prestigious and have previous historical value tend to have higher ratings, in part due to global survey problems. English and Western universities tend to have higher rankings than their Asian and African counterparts, reflecting the 
possibility that survey respondents tend to think that English is always better than the rest. Differences in each university's key objectives in research, teaching and community service, and the great diversity of programs and courses offered in universities worldwide, have contributed to inconsistencies in ranking systems. A university which is poorly ranked may be excellent in teaching or in other qualities that contribute to nation-building compared to universities with have higher rankings. Not all tools have comprehensive metrics and weights that represent all the indicators on the respective target concepts. Therefore, no ranking tool should be considered as perfect, and continuous improvement

should be called for. Relevant experts must re-examine the methodologies adopted by the major ranking systems, because decisions by prospective future students, research funding bodies, and others, should be made with informed reference to all indicators, avoiding over-reliance on university rankings. This study hopes to encourage researchers to develop more comprehensive and holistic ranking tools, aiming especially to better integrate all the factors of cultural and cross border heritage values that reflect a university's real mission, vision, and objectives.

\section{REFERENCES}

[1]. Abad-Segura, E., \& González-Zamar, M.-D. (2021). Sustainable economic development in higher education institutions: A global analysis within the SDGs framework. Journal of cleaner production, 294, 126133.

[2]. Aksu, T. (2018). THE CONCEPT OF QUALITY IN HIGHER EDUCATION. Journal of Educational \& Instructional Studies in the World, $8(1)$.

[3]. Altbach, P. G., Reisberg, L., \& Rumbley, L. E. (2019). Trends in global higher education: Tracking an academic revolution: Brill.

[4]. Brada, J. C., Bienkowski, W., \& Kuboniwa, M. (2015). International perspectives on financing higher education: Springer.

[5]. Brewer, M. L., Van Kessel, G., Sanderson, B., Naumann, F., Lane, M., Reubenson, A., \& Carter, A. (2019). Resilience in higher education students: A scoping review. Higher Education Research \& Development, 38(6), 1105-1120.

[6]. Brooks, R. (2018). Understanding the higher education student in Europe: A comparative analysis. Compare: a journal of comparative and international education, 48(4), 500-517.

[7]. Caeiro, S., Sandoval Hamón, L. A., Martins, R., \& Bayas Aldaz, C. E (2020). Sustainability assessment and benchmarking in higher education institutions-A critical reflection. Sustainability, 12(2), 543.

[8]. Chang, F. P.-C., \& Ouyang, L.-Y. (2018). Trend models on the academic ranking of world universities. International Journal of Information and Management Sciences, 29(1), 35-56.

[9]. Chowdhury, A. R. (2021). Global Ranking framework \& Indicators of Higher Educational Institutions: A Comparative Study.

[10]. Collins, F. L., \& Park, G.-S. (2016). Ranking and the multiplication of reputation: reflections from the frontier of globalizing higher education. Higher Education, 72(1), 115-129.

[11]. De La Cruz Vargas, J. A., \& Rodríguez Chávez, E. I. (2019). La investigación: Más allá del ranking de las universidades. Revista de la Facultad de Medicina Humana, 19(1), 2.

[12]. Figueroa, N., Lafortune, J., \& Saenz, A. (2018). Do you like me enough? The impact of restricting preferences ranking in a university matching process.

[13]. Han, S., \& Xu, X. (2019). How far has the state 'stepped back': an exploratory study of the changing governance of higher education in China (1978-2018). Higher Education, 78(5), 931-946.

[14]. Hauptman Komotar, M. (2019). Global university rankings and their impact on the internationalisation of higher education. European Journal of Education, 54(2), 299-310.

[15]. Hazelkorn, E. (2012). Striving for 'World Class Excellence': rankings and emerging societies. Araya D., Marber P., Higher Education in the Global Age: Universities, Interconnections and Emerging Societies. Routledge Studies in Emerging Societies Series.
[16]. Henry, C., Ghani, N. A. M., Hamid, U. M. A., \& Bakar, A. N. (2020). Factors Contributing towards Research Productivity in Higher Education. International Journal of Evaluation and Research in Education, 9(1), 203211.

[17]. Holstein, J., Starkey, K., \& Wright, M. (2018). Strategy and narrative in higher education. Strategic Organization, 16(1), 61-91.

[18]. Huang, J.-T., \& Hsu, Y.-M. (2021). Challenges and Prospects for Taiwan's Higher Education Higher Education in Taiwan (pp. 249-268): Springer.

[19]. Hung, N. T. (2021). Higher education in business: a model for international students' choice. Business Process Management Journal.

[20]. Jacqmin, J. (2021). Do ads influence rankings? Evidence from the higher education sector. Education Economics, 1-18.

[21]. Jameel, A. S., \& Ahmad, A. R. (2020). Factors impacting research productivity of academic staff at the Iraqi higher education system. International Business Education Journal, 13(1), 108-126.

[22]. Jarocka, M. (2015). Transparency of university rankings in the effective management of university. Business, management and education, 13(1), 6475.

[23]. Johnes, J. (2018). University rankings: What do they really show? Scientometrics, 115(1), 585-606.

[24]. Kaplin, W. A., Lee, B. A., Hutchens, N. H., \& Rooksby, J. H. (2019). The Law of Higher Education, A Comprehensive Guide to Legal Implications of Administrative Decision Making: John Wiley \& Sons.

[25]. Khamala, D. F., Makori, E. O., \& Njiraine, D. M. (2018). Webometrics Ranking and Its Relationship to Quality Education and Research inAcademic Institutions in Kenya. Library Philosophy and Practice, 0_1.

[26]. Kusumawati, A. (2019). Impact of digital marketing on student decisionmaking process of higher education institution: A case of Indonesia. Journal of e-Learning and Higher Education.

[27]. Lesley, P. (2018). The university challenge (2004): higher education markets and social stratification: Routledge.

[28]. Li, X., \& Thige, J. M. (2017). Benchmarking Jiangsu University to Improve Its Academic Ranking. Online Submission, 8(29), 178-187.

[29]. Lim, M. A. (2021b). Governing higher education: The PURE data system and the management of the bibliometric self. Higher Education Policy, $34(1), 238-253$.

[30]. Lin, C. Y.-Y., Edvinsson, L., Chen, J., \& Beding, T. (2012). National intellectual capital and the financial crisis in Brazil, Russia, India, China, Korea, and South Africa: Springer Science \& Business Media.

[31]. Marcel, F. (2019). Mobile augmented reality learning objects in higher education. Research in Learning Technology, 27.

[32]. Muñoz-Suárez, M., Guadalajara, N., \& Osca, J. M. (2020). A Comparative Analysis between Global University Rankings and Environmental Sustainability of Universities. Sustainability, 12(14), 5759.

[33]. Nafukho, F. M., Wekullo, C. S., \& Muyia, M. H. (2019). Examining research productivity of faculty in selected leading public universities in Kenya. International Journal of Educational Development, 66, 44-51.

[34]. Ng'ethe, J. M. (2014). Determinants of academic staff retention in public universities in Kenya.

[35]. Parvez, N., \& Agrawal, A. (2019). Assessment of sustainable development in technical higher education institutes of India. Journal of cleaner production, 214, 975-994.

[36]. Pitman, T., Edwards, D., Zhang, L.-C., Koshy, P., \& McMillan, J. (2020). Constructing a ranking of higher education institutions based on equity: is it possible or desirable? Higher Education, 80(4), 605-624.

[37]. Rauhvargers, A. (2013). Global university rankings and their impact: Report II: European University Association Brussels.

[38]. Sohail, S. S., Siddiqui, J., \& Ali, R. (2018). An OWA-based ranking approach for university books recommendation. International Journal of Intelligent Systems, 33(2), 396-416.

[39]. Song, B., Yang, X., Cao, Y., \& Xu, C. (2018). Neural collaborative ranking. Paper presented at the Proceedings of the 27th ACM International Conference on Information and Knowledge Management.

[40]. Thige, J. M., Hongbo, L., William, S. M., Hongo, D. O., Othiambo, F. A., Nderitu, C. W., \& Foku, J. M. (2021). Imploring the Gap Between Top Ranked Global Universities and Jiangsu University \& the University of Nairobi with the Aim of De-gaping Through Addressing These Disparities. American Journal of Management Science and Engineering, 6(4), 95-102.

[41]. Thige, J. M., Li, H., William, S. M., \& Athiambo, F. (2021). SEM Model Analysis on the Effect of Antecedents of the University of Nairobi and Jiangsu University's Academic Quality within the Higher Education Institutions. Creative Education, 12(8), 1901-1911.

[42]. Volpato, G., Valle, I. R., \& Bianchetti, L. (2018). Profissionais liberais na pós-graduação: motivações e interfaces entre campo profissional e acadêmico. Revista Diálogo Educacional, 18(59), 1328-1347. 